Article

\title{
Inequality Is a Problem of Inference: How People Solve the Social Puzzle of Unequal Outcomes
}

\author{
Jonathan J. B. Mijs
}

International Inequalities Institute, London School of Economics and Political Science, London WC2A 2AZ, UK; j.mijs@1se.ac.uk

Received: 30 May 2018; Accepted: 2 August 2018; Published: 7 August 2018

\begin{abstract}
A new wave of scholarship recognizes the importance of people's understanding of inequality that underlies their political convictions, civic values, and policy views. Much less is known, however, about the sources of people's different beliefs. I argue that scholarship is hampered by a lack of consensus regarding the conceptualization and measurement of inequality beliefs, in the absence of an organizing theory. To fill this gap, in this paper, I develop a framework for studying the social basis of people's explanations for inequality. I propose that people observe unequal outcomes and must infer the invisible forces that brought these about, be they meritocratic or structural in nature. In making inferences about the causes of inequality, people draw on lessons from past experience and information about the world, both of which are biased and limited by their background, social networks, and the environments they have been exposed to. Looking at inequality beliefs through this lens allows for an investigation into the kinds of experiences and environments that are particularly salient in shaping people's inferential accounts of inequality. Specifically, I make a case for investigating how socializing institutions such as schools and neighborhoods are "inferential spaces" that shape how children and young adults come to learn about their unequal society and their own place in it. I conclude by proposing testable hypotheses and implications for research.
\end{abstract}

Keywords: inequality; meritocracy; inference; social context; institutions

\section{Introduction}

As David Hume knew in 1777, causality cannot be observed; we see things happening, we find patterns and we "make" causality. Drawing on advances in neuroimaging, scholars are closer than ever to describing the neural process underlying causal inference. The evidence suggests people have a "theory of mind" that allows them to reason about the unobserved causes of the things that happen in their lives. Descriptions of this process vary, but the consensus is that people make causal inferences based on available information and past experiences, and update their beliefs based on new information [1-3]. A particularly pressing social phenomenon in need of causal explanation is social inequality. Unequal outcomes confront us in the form of our daily struggles and achievements, our friends and family's plight, as well as the strangers we meet, be they awash in riches or in financial need. Our experiences and observations require interpretation, and people in practice come up with a variety of explanations, which social scientists refer to as inequality beliefs. Scholarship describes wide-ranging differences in people's beliefs about inequality but has not made much progress in explaining why people understand inequality in one way or another [4-6]. The study of inequality beliefs is in need of an organizing framework.

In this paper, I develop such a framework and discuss its implications for future research. I propose that we conceive of beliefs about inequality as a special case of causal inference, where people make sense of (observed) unequal outcomes by inferring the (unobserved) social forces that brought these about. I suggest that this process is deeply socially bounded: in making inferences about the 
causes of inequality, people draw on lessons from past experiences and information about the world, both of which are biased and limited by their background, social networks, and the environments they have been exposed to. Looking at inequality beliefs through this lens allows for an investigation into the kinds of experiences and environments that are particularly salient in shaping people's inferential accounts of inequality. In what follows, I review the extant social science literature on inequality beliefs, before presenting a framework for systematically studying the social origins and development of people's inferences about inequality. Specifically, I make a case for investigating how socializing institutions such as schools and neighborhoods are "inferential spaces" that shape how children and young adults come to learn about their unequal society and their own place in it.

\section{Beliefs about Inequality and Their Consequences}

Inequality is like the manure of the elephant in the room; a constant reminder that something just doesn't smell right. But as with all our senses, people perceive differently: for some, the stench is unbearable, while others manage to cope or even learn to appreciate the scent. An important source of our different experiences of inequality, and our evaluation thereof, is how we have learned to make sense of unequal outcomes. Some people hold inequalities to be the result of a fair, "meritocratic" race that is decided by hard work and effort alone. Others believe the race is fixed: some people, because of the color of their skin, gender, or their parents' resources, among other things they cannot control, have a much better shot at winning than do others. The former perspective emphasizes the actions of individuals and the things they have control over. The latter view highlights the role of situational or structural factors that are beyond an individual's control. Following Kluegel and Smith, I refer to the two, respectively, as individualist and structuralist beliefs about inequality [7]. ${ }^{1}$

Scholars have long been interested in inequality beliefs for the way people understand inequality is often the starting point of their politics and policy views as well as their feelings of solidarity toward others-or lack thereof [8,9]. Moreover, research suggests that political attitudes and policy preferences on topics such as the welfare state, redistributive taxation, and national health coverage, reflect not just what people want their society to be; citizens' responses to questions about redistribution, and solidarity more generally, are based on their explanations of the causes of poverty and wealth [8-12]. Similarly, attitudes toward policies redressing racial inequalities, research suggests, are grounded in people's explanations for racial inequality [13-15]. Even a person's (political) response to crime is shaped by what they think causes criminal behavior: people who hold structuralist beliefs about crime, emphasizing the role of factors outside a person's control that may lead him or her to deviance, are much more likely than individualists to favor a non-punitive response to crime [16]. In short, these studies suggest that there are important consequences to whether one understands societal positions as accomplished by individual efforts or failings or, alternatively, as the result of discrimination, the limits or fortunes of birth, and other (structural) factors beyond a person's control.

Another line of research describes how people's understanding of what opportunities are or are not available to them impacts their motivation, ambition, and efforts. This research tradition goes back to Merton's structural strain theory [17]. It posits that a person's actions can be understood as an interaction between the goals that person wants to pursue and the means they think are available or unavailable to them, given structural constraints. In other words, a person's efforts are shaped by the balance of individual and structural factors that they think explains success and failure. Sociological research since has powerfully described how, for instance, in education, students' understanding of success as structurally determined can give rise to a self-fulfilling prophecy of rejecting school and all things academic [18-20]. Ogbu's "burden of acting white" thesis similarly asserts that the racial

1 In what follows, my focus is on inequality beliefs conceived strictly as people's understanding of the individual or structural causes of (unequal) social outcomes. I acknowledge that these beliefs are related to people's concerns about inequality, their perceptions of the extent of inequality in society, and their ideas regarding what to do about it [6], but the topic of this paper is limited to the former. 
achievement gap can be explained, in part, by black students opposing school because they think the structural barriers to achievement are insurmountable [18]. While research since has refuted the notion, these later studies at the same time show how minority students' academic efforts reflect a (sometimes unrealistic) meritocratic belief that hard work makes for societal success [21,22]. Taken together, these findings underline the importance of understanding what drives people's different beliefs about inequality, which is the topic to which I now turn.

\section{Psychological Explanations of Inequality Beliefs}

Social psychological research from the 1960s and 1970s on has shown great interest in how people explain unequal social outcomes. Research has produced two general accounts of what drives people's beliefs about inequality: self-interest and dominant ideology. In what follows, I briefly describe each perspective.

Psychologists use the term "fundamental attribution error" to describe the tendency to attribute social outcomes to hard work and effort for such serves our own interest, as when we attribute our own success to individual factors, but our failures to structural factors [23,24]. Similarly, the 'belief in a just world' theory suggests that people's individualist beliefs about inequality stem from people wanting to believe that they live in a world that is, at its core, just—as illustrated by idioms as "you got what was coming to you," "what goes around comes around," and "you reap what you sow" [25]. Believing in a just world relieves us of the moral responsibility to care for other people and keeps us from worrying about our future; it turns unequal outcomes into the (just) results of individuals' talents and efforts.

There are two empirical challenges to these theories. First, they fail to account for the observation that many people do not think they live in a just world [26,27]. In fact, Kluegel and Smith report that as much as 80 percent of their respondents said they live in an unequal society where social outcomes are determined by structural forces beyond people's control, such as discrimination and the privileges of family wealth [7]. While recent surveys do indicate that people tend to underestimate the extent of inequality in their society, there is little evidence to suggest that they believe theirs is a just world $[28,29]$. Second, self-interest does not help explain how inequality beliefs oftentimes go against a person's interests, as when underprivileged groups explain their own position as resulting from differences in effort and ambition [30-33] or when privileged social groups acknowledge their own structural advantages [34].

Social psychology offers an alternative explanation in system justification theory. System justification theory describes a socialization process, whereby people come to adopt a dominant belief about inequality, whether or not it is in their interests to do so $[35,36]$. Referencing Karl Marx, it is argued that, "because the ideas of the dominant tend to become the ideas of the dominated, system-justifying stereotypes may be advanced by even those who stand to lose from it" [36]. In short, growing up with the American dream makes one believe in it. Newman, for instance, vividly describes how unemployed American workers, having internalized the American dream, blame themselves for their dismissal and for their failure to find new work [32]. Sharone's study of lay-offs in the technology sector following the IT bubble burst in the early 2000s similarly describes how people facing unemployment in San Francisco primarily blamed themselves for failing to find work despite the well-documented structural causes of their predicament [37].

Cultural psychologists describe cultural differences between citizens of the world that can be attributed to people's socialization into different national ideologies-e.g., Japanese citizens hold very different inequality beliefs from Americans, who in turn differ from Brazilians [38]. If this perspective correctly describes a universal psychological tendency as well as a source of cultural variation, it still faces a problem in the documented variation in inequality beliefs within societies. Studies in this tradition for instance find that beliefs vary with people's ethnicity, race, and income $[39,40]$. To their credit, scholars acknowledge the problem [41], but they do not have a good answer for why people have different beliefs. As Crittenden observed, "striking to a sociologist ( . . ) is how little studied are 
the social conditions under which different attributional tendencies emerge" [42]. The next section considers what these conditions might be.

\section{Toward a Sociological Approach to Studying Inequality Beliefs}

Starting with Kluegel and Smith, sociologists have studied patterns of variation in inequality beliefs. Studies suggest that beliefs about inequality vary with age, income, education, religion, and race, and that such differences are observable already with children 14 years of age [43-46]. Cross-country research similarly shows patterns of variation between citizens of different nations and regions of the world $[6,14,47,48]$. Table 1 gives an overview of findings.

While these studies suggest a host of covariates of inequality beliefs, for almost every factor suggested, there is another study that reports a non-significant relationship. Furthermore, there is little agreement over how these factors are related to inequality beliefs and what the direction of causality is. For instance, most studies suggest women are more likely to have a structural understanding of inequality than men, but three studies report that women and girls have more individualist beliefs [34,44,49]. Likewise, most research shows a positive relationship between education and structuralist beliefs about inequality $[45,50,51]$, but some studies suggest more highly educated people are actually more likely to have an understanding of inequality that includes both individual and structural factors [52], whereas other studies find no significant effect [49] or even indicate a negative relationship $[16,53]$.

The discrepancy in findings is attributable, in part, to differences in the conceptualization and measurement of inequality beliefs. For instance, some studies investigate the socio-demographic correlates of people's explanations for unequal outcomes in general, while others focus on specific explanations for poverty $[45,54]$ or racial inequality $[46,55]$. This difference in focus is reflected also in the different data sources used, ranging from theoretical samples [54] to probability samples of city or state populations $[45,51,56]$ and the General Social Survey (GSS), representative of the entire US population $[16,46,49,55,57]$.

Even within the set of studies based on the same GSS data, however, some scholars rely on questions gauging people's explanations of racial inequality ${ }^{2}$ whereas others center on people's responses to a question about the causes of income inequality. ${ }^{3}$ Another likely source of different findings stems from authors' measurement strategy. Important decisions include how to measure individualist and structuralist responses, whether or not to include a mixed-category in-between, and whether to investigate differences in beliefs by race [15], gender [46], or both [55]. Such choices have substantial implications. For example, Kluegel, taking the former approach, finds that women are more likely than men to hold a mixed-account of inequality, Reynolds and Xian find that women are more likely than men to understand inequality in individualist terms, and Hunt highlights differences between white women, who explain inequality in more structural terms, and black women, who explain inequality as the result of individual factors.

2 "On the average blacks have worse jobs, income, and housing than white people. Do you think these differences are: A. Mainly due to discrimination; B. Because most blacks have less in-born ability to learn; C. Because most blacks don't have the chance for education that it takes to rise out of poverty; D. Because most blacks just don't have the motivation or will power to pull themselves out of poverty."

3 "How important is each of the following factors in determining whether people in the U.S. get ahead or fall behind economically. After each please tell me if it is one of the most important factors determining whether or not Americans get ahead or fall behind economically, very important, somewhat important, not too important or not important at all? Hard work; Ambition; Having a good education; Having wealthy parent; Having well-educated parents; Knowing the right people; Having political connections; A person's race; A person's religion; A person's sex." 
Table 1. Summary of findings for studies on the covariates of inequality beliefs.

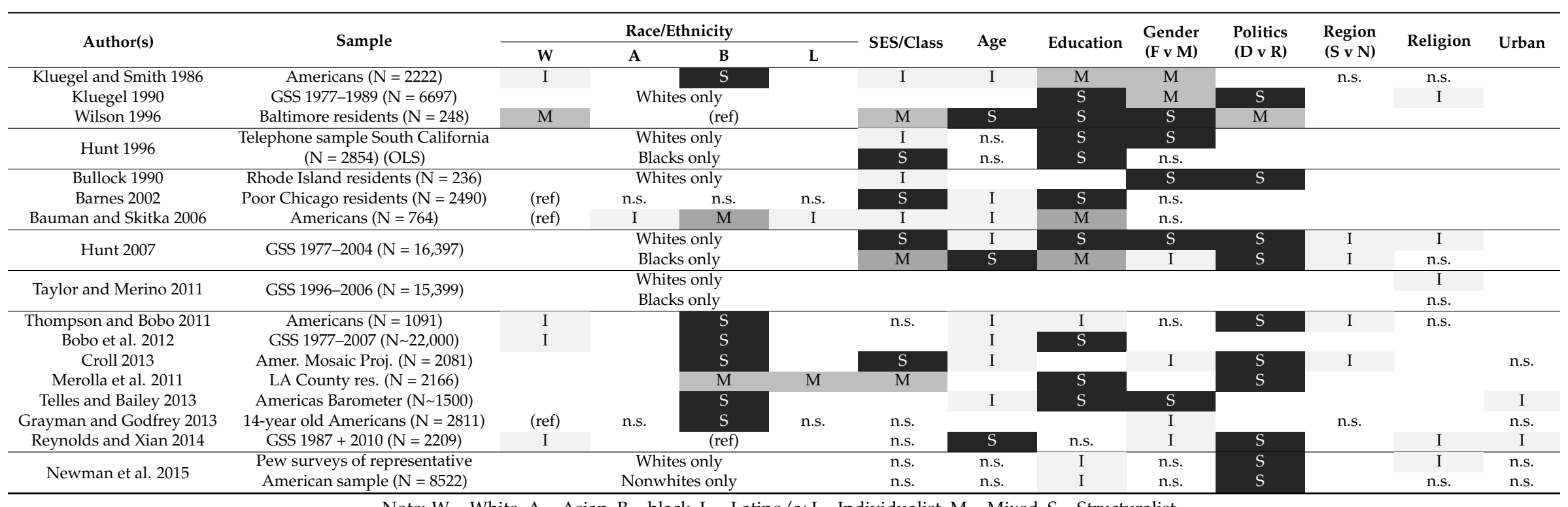

Note: $\mathrm{W}=$ White, $\mathrm{A}=$ Asian, $\mathrm{B}=$ black, $\mathrm{L}=$ Latino/a; $\mathrm{I}=$ Individualist, $\mathrm{M}=$ Mixed, $\mathrm{S}=$ Structuralist. 
In sum, thirty years of scholarship since Kluegel and Smith's Beliefs about Inequality has not produced a comprehensive account that explains the observed patterns of co-variation. We need a theoretical framework to integrate these studies and provide a roadmap for research. As a starting point for such a framework, consider what neuroscientists call "theory of mind":

Social life depends on developing an understanding of other people's behavior: why they do the things they do, and what they are likely to do next. Critically, though, the externally observable actions are just observable consequences of an unobservable, internal causal structure: the person's goals and intentions, beliefs and desires, preferences and personality traits. Thus, a cornerstone of the human capacity for social cognition is the ability to reason about these invisible causes. [2]

Scholarship in neuroscience [2], developmental psychology [1], and cognitive science [3] has fruitfully drawn on advances in brain imaging to study the ways in which people make inferences about other people's actions and intentions. The "theory of mind" they describe is an inferential process whereby people draw on lessons from past experiences and update their beliefs based on new information. Experience, I argue, is where sociology comes back in.

I propose that we think of inequality beliefs as problems of inference: people are, on a regular basis, confronted by unequal social outcomes-be it success or failure, wealth or poverty-and must make inferences about the unobserved social processes that underlie these outcomes. To theory of mind, then, social science has one crucial addition to offer: the experiences people draw on in making causal inferences are socially shaped. Thus, the key empirical question is as follows: what are the kinds of social experiences that are especially salient in shaping our inferential accounts of inequality? In the next section I suggest one way of systematically studying the link between experience and inference: by focusing on the social institutions that provide the immediate social context to our experiences.

\section{Institutions as Inferential Spaces: Linking Experience to Understanding}

In learning about inequality, a young person must draw from experience. Meritocracy is a powerful narrative, produced and reproduced by movie makers, authors, parents, and politicians $[27,58,59]$. Developing a structural understanding of inequality requires that a person has some evidence of non-meritocratic processes. A person is more likely to believe that money can buy you an education, that family connections can get you a job, or that the "right" tone of skin can get you out of a speeding ticket, if they, or someone close to them, experienced one or more of these things.

Race, sex, and religion are proxies for experiences with structural inequality, insomuch as people live in societies where such identity categories are subject to discrimination. That is, having a gender, sexuality, race or religion that faces discrimination, makes a person more likely to directly witness how people's lives are impacted by non-meritocratic processes (e.g., discrimination, favoritism). The same is true of social class, especially in societies where status differences are salient in everyday interactions, through speech, appearance, and other status markers [60,61].

A second source of experiences with inequality is the social environment in which people grow up, which can be more or less racially and socioeconomically heterogeneous. I argue that encounters with people from a different racial or socioeconomic background may introduce information indicative of the structural sources of inequality in society, namely how race and family background help or hinder social mobility [51,61-63]. Such encounters produce experiences which may lead emerging adults to re-evaluate their worldview [64-66]. Conversely, an environment low in ethnoracial and socioeconomic heterogeneity may keep young people from this kind of information and thus does not provide counterevidence to the dominant meritocratic view of society [67-69].

Sampson and Bartusch go as far as to suggest we conceptualize beliefs as stemming from different "cognitive landscapes" at the neighborhood and community level [70]. This concept helps identify the fact that, certainly in America, being poor, black, and living in particular neighborhoods importantly shapes a person's social group and peers, interactions with authorities, and exposure to violence, 
among other formative experiences [71,72]. Whereas, arguably, this applies to all sorts of environments, it may be especially true for socializing institutions such as neighborhoods and schools [71,73,74]. These institutions, more than others, constitute the context of adolescence, which research suggests is when young adults are particularly impressionable. Moreover, beliefs formed in these years are quite durable throughout a person's life [75-77]. Inasmuch as they provide a context to a person's experiences and interactions with others, I argue, schools and neighborhoods are inferential spaces: they shape the development of a person's inequality beliefs by exposing that person to a certain type and range of information, but not to their counterfactuals.

Specifically, I conceive of an inferential process whereby people draw from direct experiences and information available to them to develop an understanding of social inequality. That is, the way people learn from their homogenous or heterogeneous environment is not necessarily based on what they are explicitly taught or told, but instead entails inferential work, whereby a person constructs a model of the world based on the information available to them [78,79]. In other words, inferential work is a distinctly inductive process, as contrasted to the deductive manner through which a person may arrive at an individualist explanation for unequal outcomes based on a general belief in meritocracy.

This process shares features of Zaller's "Receive, Accept, Sample" (RAS) model on how people form political preferences based on information from mass media [80]: political opinions are a product of people's varying exposure and attention to political information in the media, especially the ideas that appear immediately salient to them. The extent to which people accept new information however is based on how knowledgeable they are on the topic, i.e., on their exposure to previous information. A similar self-reinforcing process is at play in the formation of people's inequality beliefs. Where the inferential process differs from Zaller's model is in the primacy of experiential knowledge: despite all the news on inequality, for many people, the world as presented in the media, or depicted by politicians, may not correspond to their lived experience. A person who has come to understand unequal outcomes in individualist terms may not accept at face-value an account of structural (dis)advantage. Similarly, a person who through their experiences has come to see inequality in structural terms will likely have a critical response to meritocratic claims. The implication is that inequality beliefs tend to have a self-reinforcing quality that is hard to break until some critical mass of new information and experience has been reached.

The hypothesized role of experiences is akin to contact theory which states that exposure to ethnic, racial, or socioeconomic heterogeneity can lead to a reduction in prejudice and improve intergroup tolerance and sympathy [81]. However, I argue that these are best considered as possible outcomes of a cognitive process of (improved) understanding of the other group's plight. That is, experiences with heterogeneity may impact, through an inferential process, a person's beliefs about inequality and, by implication, the deservingness of people in power and in need. Whether these (updated) beliefs translate into affects, empathy, politics, and intergroup relations, is another matter. Different settings-interactional, local, or national-may give rise to forces that either promote or suppress change. By more systematically studying the links between experience, beliefs, and attitudes we should get better answers to questions like, when do experiences and interactions with heterogeneity translate into belief change, and under what conditions do such changes impact a person's attitudes about people from a different class or racial background?

The following formally presents my theoretical framework and expectations in terms of an inferential model of belief formation: people exposed to heterogeneous environments, having learned about the role of structural factors in shaping life outcomes, have a causal model of inequality that features more structural factors as compared to people who have been exposed mainly to homogeneous institutions.

1. To explain specific life outcomes, and inequality more broadly, people implicitly construct a causal model of the social world that includes a vector of variables, $X$, for all factors they think are relevant to explaining the observed outcome, $\mathrm{Y}$. We can express structural factors as $\mathrm{X}_{\text {str }}$ and individual factors as $X_{\text {ind }}$, such that 


$$
\mathrm{Y}=\mathrm{X}_{\mathrm{str}}+\mathrm{X}_{\mathrm{ind}}
$$

2. The variables that enter a person's model of the social world are based in large part on how salient individual and structural factors, $\mathrm{E}_{\mathrm{ind}}$ and $\mathrm{E}_{\mathrm{str}}$, are in a person's own experiences and observations, as well as on information, $\mathrm{I}_{\text {ind }}$ and $\mathrm{I}_{\text {str }}$, people collect from other sources, conditional on whether this information seems plausible in light of their experiences and observations, such that

$$
Y=X_{\text {str }}\left(E_{\text {str }}+I_{\text {str }} \mid E_{\text {str }}\right)+X_{\text {ind }}\left(E_{\text {ind }}+I_{\text {ind }} \mid E_{\text {ind }}\right)
$$

3. For a person to experience the salience of an individual or structural factor, he or she must be able to observe variation both in the factor and in the relevant outcome-e.g., variation in effort and corresponding reward, variation in race/ethnicity and corresponding discrimination. A person's assessment of the salience of individual and structural factors, $E_{\text {ind }}$ and $E_{\text {str }}$, thus varies with the extent to which they have had an opportunity to observe or experience variation in these factors.

Opportunities to experience or observe variation in individual and structural factors are conditioned by the composition of the institutions in which people grow up and learn about the social world: the more socioeconomically and/or ethnoracially heterogeneous an institution, $\mathrm{H}$, the more opportunities a person has for observing and experiencing the salience of race and family resources (structural factors) and conversely the more homogenous an institution the more salient are individual factors, relative to structural factors, such that

$$
\mathrm{H} \uparrow \rightarrow \mathrm{E}_{\text {str }} \uparrow \mathrm{E}_{\text {ind }} \downarrow \text { and } \mathrm{H} \downarrow \rightarrow \mathrm{E}_{\text {ind }} \uparrow \mathrm{E}_{\text {str }} \downarrow
$$

4. In sum, the more time a person has spent in heterogeneous institutions, the more important structural factors feature in their model of the social world, and the less prominently do individual factors feature.

$$
\mathrm{Y}=\mathrm{X}_{\mathrm{str}}(\mathrm{H})+\mathrm{X}_{\text {ind }}(-\mathrm{H})
$$

Homogeneity reduces a person's exposure to explanatory variables other than a person's attitudes and actions, that may importantly affect social outcomes; e.g., the kind of family resources one can or cannot draw on, connections that one may have or lack, the way one is treated by others based on the color of their skin. This leads to a tendency to overestimate the influence of an individual's actions. In other words, homogeneous settings foster the illusion of a direct correspondence between hard work and success (or laziness and failure) by effectively eliminating from observation, and excising from the setting, all other factors of difference (things people have no control over).

What belies this relationship can alternatively be stated in terms of differences in counterfactual information. That is, the homogeneity or heterogeneity of an institutions shapes the available counterfactual information that a person can draw on in making causal inferences. Among other things, it may shape a person's view of the "ordinary person" counterfactual, or benchmark, if you will, to compare with the person they are evaluating; it may shape their understanding of the counterfactual outcome, i.e., what would have happened if it were not for the person's action(s); and it may shape what kind of information a person thinks of as relevant to take into account when making these inferences.

Zooming out, Figure 1 graphically illustrates the hypothesized links between institutions (A), causal inference (B), and its implications for people's political attitudes, citizenship behavior, and moral judgements $(\mathrm{C})$ - as documented by the literature reviewed in Section 2. In sum, I describe an inferential process whereby people learn about the world they live in by drawing conclusions supported by their observations and experiences. Specifically, I propose that one of the ways (young) people make sense of their world is by constructing a causal model of unequal outcomes as explained by the variables they have understood to be most important (B). The implication is that people's causal inferences about success and failure - and, consequently, of inequality—are shaped by the type of institutional 
environment they have been durably exposed to (A). I expect people who are durably exposed to more heterogeneity to develop a more structuralist understanding of inequality over time, whereas I expect people in more homogenous settings to develop more individualist beliefs about inequality. What kind of beliefs people develop, in turn, impacts their political attitudes and policy preferences as well as their feelings of solidarity more generally (C).

\section{Implications for Research}

The inferential model of belief formation spells out a number of empirical predictions. It acknowledges that people are psychologically biased as well as culturally primed toward explaining unequal outcomes in individualist, meritocratic, terms. However, not everyone is similarly biased. The extent to which people are, is socially shaped by people's experience with and exposure to structural forces driving unequal outcomes.

Individual characteristics, like a person's race or gender, are imperfect proxies for such experiences. Reflective of their greater exposure to discrimination, women generally are less likely than men to understand outcomes in purely meritocratic terms [14,45,51,55], and so are African Americans, as compared with white Americans $[7,15,16,44,52]$. These associations however depend on context, which may explain why some surveys report contradictory patterns. To see how, researchers should situate individuals in their social context. In line with predictions from the inferential model, studies suggest that women are relatively more likely to explain outcomes meritocratically, and less likely to recognize structural barriers, when they are durably exposed to homogenous, gender-segregated, environments-as is true for women in engineering or male-dominated corporate settings [82-84]. The same holds for men in such settings, who in the absence of exposure to diversity in status and gender, infer meritocratic explanations for the causes of sex differences in job title and income [85-87].

Studies similarly describe how the link between race, ethnicity and socioeconomic status, on the one side, and people's beliefs about inequality, on the other, is mediated by people's exposure to heterogeneity. As Edmiston concludes from his interviews with affluent and poor Brits and New Zealanders,

Affluent participants who had sustained interaction with, or experience of, structural constraints were much more likely to recognize the factors that might mitigate an individual's responsibility for their situation or actions. Knowledge accumulation, therefore, appears to mediate awareness and appreciation of the relationship between structure and agency. [67]

One source of such experiences is the neighborhood a person lives in: people living in socioeconomically homogeneous neighborhoods tend to hold meritocratic beliefs, whereas people in economically heterogeneous areas are more likely to explain outcomes in structural terms [56,88,89]. Underlying this association is mechanistic evidence that people make inferences about their unequal society based on their local experiences [69,78].

Other studies point to the role of schools in exposing students to homogenous or heterogeneous settings, such that "youth of color attending segregated schools experience structural discrimination on a daily basis, but they lack the opportunity to make between-race comparisons on a daily basis. Students who cross boundaries, in other words, are more likely to see discrimination than those who do not make these journeys" [74]. Mijs describes how secondary school students in more (socioeconomically) homogeneous school environments are more likely to explain poor school results in individualist terms and internalize failure, compared to students in more heterogeneous environments, who see school outcomes as the result of a range of factors both within and beyond their control [90]. 


\section{A. Institutions}

Socializing institutions are inferential spaces. Each exposes people to a certain kind and range of differences between people, but not others

\section{B. Beliefs}

Theinferential spaceshapes people's aspirations, expectations, evaluations of self and others, and their inequality beliefs

\section{Cons equences}

Inequality beliefs provide the basis

for political attitudes, policy preferences, citizenship behavior, and moral evaluations of others

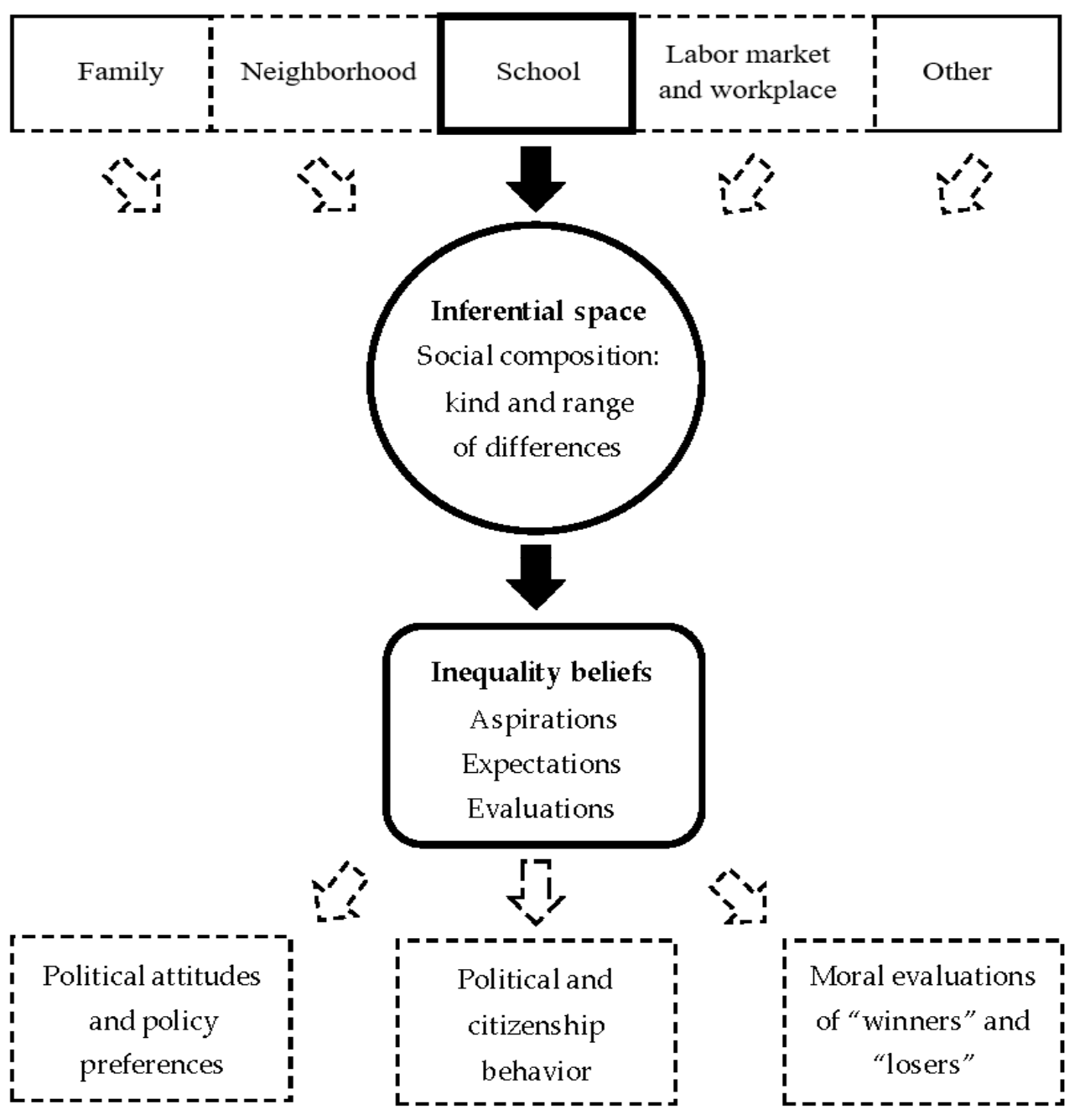

Figure 1. How social institutions shape the development of inequality beliefs. 
Crucial evidence that inequality beliefs are open to change, comes from longitudinal studies of college students. Sidanius et al., describe a "liberalizing effect" of college: over the college years, students tend to develop more liberal political attitudes and a more empathetic understanding of minorities' plight [91]. This liberalizing tendency is especially strong for students who experienced heterogeneity through their social interactions on campus or by having a roommate from a different ethnic or racial background. Conversely, Mendelberg et al. describe how students at socioeconomically homogenous colleges develop a more conservative outlook and corresponding set of beliefs [92]. Mijs describes how the same is true with respect to students' beliefs about meritocracy and the causes of racial inequality: students who experience ethnic, racial and socioeconomic heterogeneity through their roommate, in their social interactions, or on campus more generally, develop a more structural understanding of inequality, whereas students without such experiences grow more convinced that theirs is a meritocratic society [93]. Khan [94] and Gaztambide-Fernández [95] similarly describe how most students at the homogenous and exclusive "elite institutions" they studied developed a meritocratic understanding of social inequality in their society and came to think of themselves as deserving of a place at the top.

In sum, the inferential model of belief formation seems to stand its empirical ground. Future work will show its uses and its limits. At minimum, the framework here presented should provide conceptual clarity and offer a common ground for the wide-ranging research interest in inequality beliefs across social science disciplines. I conclude by offering five suggestions for how to proceed, empirically.

First, inequality beliefs are best considered cognitive concepts, distinct from norms and preferences [6,7]. That is, a person may have a belief about how to world is and works (i.e., how much inequality there is and what processes generate it) that is different from, even conflicting with, how they would like the world to be and how they would like to get there (i.e., through what interventions, politics and policies).

Second, inequality beliefs are best assessed as detailed explanations of life outcomes, adding up to a more or less coherent perspective. Patterns of explanations may differ by topic or domain. For instance, people may hold beliefs that can be characterized as individualist when explaining life outcomes in education or work, but take a more structuralist form when thinking about the determinants of crime. It is an empirical question whether these domain differences are the product of people's experiences with regard to these outcomes, or whether they reflect different notions of how cause-and-effect and responsibility apply to these domains [5].

Third, inequality beliefs are best conceptualized as multidimensional: whereas there is a negative relationship between structural and individualist beliefs, there is no evidence to suggest that the two are in a zero sum relationship [8,15]. Just as any single life outcome is best explained by a multitude of factors, we can think of a person's inequality beliefs as being marked by a combination-or repertoire-of individual and structural factors that can be applied-or activated-to explain various life outcomes [96].

Operationalizing a multidimensional concept requires some kind of "flattening" for the purposes of measurement. Table 2 illustrates one way to do so. Dichotomizing beliefs about hard work (individualist beliefs) and beliefs about the role of structural forces allows for an operationalization of four multinomial categories that describe a person's inequality beliefs. We can label these as "predominantly individualist" / "predominantly structuralist" / "mixed beliefs" and a final category which denotes the belief that neither hard work nor structural forces explain societal success-one way to think of this position is as emphasizing the importance of chance. The numbers here provided for illustrative purposes could be an empirical record of a single person's beliefs or that of a large group of people, such as the typical beliefs held by citizens of one country; e.g., while approximately 75 percent of people $(55+20)$ may think that societal success is the product of hard work, a large share of these people (20/75) could also think structural factors are part of the explanation, which is how McCall describes the typical American's view of inequality [27]. 
Table 2. Two-dimensional conceptualization of a person's inequality beliefs.

\begin{tabular}{|c|c|c|c|}
\hline \multirow{2}{*}{ Societal Success } & \multicolumn{3}{|c|}{ Is the Product of Hard Work } \\
\hline & & Disagree & Agree \\
\hline Is the product of & Disagree & $5 \%$ & $55 \%$ \\
\hline structural forces & Agree & $20 \%$ & $20 \%$ \\
\hline
\end{tabular}

Fourth, inequality beliefs are best studied longitudinally, as a person's evolving understanding of society and their own place in it. As is, repeated representative surveys like the GSS and the International Social Survey Programme (ISSP) are the best of a small set of sources for studying changing beliefs about inequality, but only at the level of society. To study whether and how individuals change their understanding of inequality, as a factor of their changing environment or of particular experiences and events in their life, we need more detailed panel data. An especially important question to consider is if and how beliefs solidify during the life course. Research in developmental (neuro)psychology suggests that children make sense of their world based on their immediate environment, starting from around the age of eight and we know that different inequality beliefs are observable at least by age 14 [44]. Further, research on lifespan political socialization suggests that young adults are particularly impressionable in their college years, and that beliefs formed in those years are quite durable over a person's life course [75-77]. It remains an open question however when the impact of experiences reaches its peak and if and when experiences with homogeneity/heterogeneity reach a saturation point, as implied by the theoretical model.

Fifth, and related to the previous suggestion, inequality beliefs are best collected contextually. Whether through qualitative methods or by means of a survey questionnaire, it is crucial that scholars collect as much relevant contextual data to situate people's understanding of inequality in their current and past institutional environment (e.g., in the neighborhood, in school and at the workplace). A survey approach would especially benefit from the linkage of geolocation data and administrative records with individuals' self-reported descriptions of their institutions. Regional geolocation data has proven useful, for instance, to describe the link between growing up in an economic recession and a person's views about the causes of economic fortunes [97]. Combining objective and subjective measures of institutional environment would allow for a more robust measurement of people's perceived and experienced context, and would enable us to study how such perceptions and experiences may shape belief formation. An example of a more qualitative approach is to define two or more groups of youth growing up in settings varying in heterogeneity, and ask respondents to keep a diary to record their thoughts on a set of events or life outcomes common to all groups. Whereas a survey would bring out most clearly the likely patterns of variation, comparing diary entries may yield more nuance and insight into how people make sense of key events in their lives, and their causes.

\section{Conclusions}

From Julius Caesar's self-described decisive victory over the Gauls to the superior ingenuity of David in defeating Goliath, Western culture is rife with stories of individual accomplishment. We celebrate the success of leaders in business, science, and sports, and when we do, we tend to attribute the outcome of events to the achievements of (extraordinary) individuals. An alternative worldview is one that acknowledges the role of structural forces in shaping our lives: perhaps some of us did not have the same opportunities as others. Indeed, social science research has well-documented the (structural) advantages that benefit people with money, resources, and connections in getting ahead in life. Those same processes constitute barriers to people with fewer economic, cultural, and social means, and similar disadvantages face people of color, women, and other minorities.

In this paper I have argued that our different experiences mean that our appreciation of these processes varies. Consequently, we see inequality through the lens of our unique biography, explaining unequal outcomes in terms that resonate with our particular set of experiences. Whereas any person's 
life is singular, we find common ground with others who grew up in similar circumstances; with whom we share a common outlook on life. What belies our outlook on life, I suggest, is shaped to an important degree by the institutions that provide the immediate context to our social life, especially in childhood and adolescence. To the extent that they do, institutions like neighborhoods and schools are "inferential spaces" that shape how we learn about the world by providing access to certain experiences and information, but not their counterfactuals. Socioeconomically and racially heterogeneous institutions teach us about the ways that race and class matter; lessons that are not as easily learned when growing up in homogenous institutions, with mostly people of the same income and racial group.

Situating people's inequality beliefs in their socially-bounded experiences helps make sense of the contradictory findings reported in studies that attempt to explain people's inequality beliefs in terms of individual characteristics, such as gender, race, education, or socio-economic status. Specifically, looking at inequality through the lens of inferential spaces explains why people living in homogeneous neighborhoods hold more meritocratic beliefs about inequality, whereas people in heterogeneous areas understand unequal outcomes in structural terms [56,88,89]. Men and women explain sex differences in status and income in meritocratic terms, in the absence of exposure to diversity in status and gender [82-87]. Students who experience heterogeneity develop a more structural understanding of school outcomes [90] and unequal outcomes more generally [93], whereas students without such experiences became more convinced that theirs is a meritocratic society [93-95]. Future research will show the uses and limits of the inferential model of belief formation here presented.

Funding: This research received no external funding.

Conflicts of Interest: The author declares no conflict of interest.

\section{References}

1. Baron-Cohen, S.; Lombardo, M.; Tager-Flusberg, H. (Eds.) Understanding Other Minds: Perspectives from Developmental Social Neuroscience; Oxford University Press: London, UK, 2013; ISBN 978-0-19-969297-2.

2. Koster-Hale, J.; Saxe, R. Theory of mind: A neural prediction problem. Neuron 2013, 79, 836-848. [CrossRef] [PubMed]

3. Tenenbaum, J.B.; Kemp, C.; Griffiths, T.L.; Goodman, N.D. How to grow a mind: Statistics, structure, and abstraction. Science 2011, 331, 1279-1285. [CrossRef] [PubMed]

4. Hunt, M.O.; Bullock, H.E. Ideologies and beliefs about poverty. In the Oxford Handbook of the Social Science of Poverty; Oxford University Press: New York, NY, USA, 2016; pp. 93-116.

5. Mijs, J.J.B. The unfulfillable promise of meritocracy: Three lessons and their implications for justice in education. Soc. Just. Res. 2016, 29, 14-34. [CrossRef]

6. Janmaat, J.G. Subjective inequality: A review of international comparative studies on people's views about inequality. Eur. J. Sociol. 2013, 54, 357-389. [CrossRef]

7. Kluegel, J.R.; Smith, E.R. Beliefs about Inequality: Americans' Views of What Is and What Ought to Be; Transaction Publishers: New York, NY, USA, 1986; ISBN 978-0-202-30327-7.

8. Bobo, L.D. Social responsibility, individualism, and redistributive policies. Sociol. Forum 1991, 6, 71-92. [CrossRef]

9. Kraus, M.W.; Keltner, D. Social class rank, essentialism, and punitive judgment. J. Pers. Soc. Psychol. 2013, 105, 247-261. [CrossRef] [PubMed]

10. Applebaum, L.D. The influence of perceived deservingness on policy decisions regarding aid to the poor. Polit. Psychol. 2001, 22, 419-442. [CrossRef]

11. Paskov, M.; Dewilde, C. Income inequality and solidarity in Europe. Res. Soc. Stratif. Mobil. 2012, 30, 415-432. [CrossRef]

12. Bullock, H.E.; Williams, W.R.; Limbert, W.M. Predicting support for welfare policies: The impact of attributions and beliefs about inequality. J. Poverty 2003, 7, 35-56. [CrossRef]

13. Gilens, M. Why Americans Hate Welfare: Race, Media, and the Politics of Antipoverty Policy; University of Chicago Press: Chicago, IL, USA, 2009; ISBN 978-0-226-29366-0. 
14. Telles, E.; Bailey, S. Understanding Latin American beliefs about racial inequality. Am. J. Sociol. 2013, 118, 1559-1595. [CrossRef]

15. Bobo, L.D.; Charles, C.Z.; Krysan, M.; Simmons, A.D. The real record on racial attitudes. In Social Trends in American Life: Findings from the General Social Survey Since 1972; Princeton University Press: Princeton, NJ, USA, 2012; pp. 38-83.

16. Thompson, V.R.; Bobo, L.D. Thinking about crime: Race and lay accounts of lawbreaking behavior. Ann. Am. Acad. Pol. Soc. Sci. 2011, 634, 16-38. [CrossRef]

17. Merton, R.K. Social Theory and Social Structure; Free Press: New York, NY, USA, 1957.

18. Fordham, S.; Ogbu, J.U. Black students' school success: Coping with the "burden of 'acting white'”. Urban Rev. 1986, 18, 176-206. [CrossRef]

19. Willis, P.E. Learning to Labor: How Working Class Kids Get Working Class Jobs; Columbia University Press: New York, NY, USA, 1977; ISBN 978-0-231-05357-0.

20. Mijs, J.J.B.; Paulle, B. A burden of acting wise: Ambiguity about hard work and oppositional peer dynamics at an elite school in The Netherlands. Intercult. Educ. 2016, 27, 22-38. [CrossRef]

21. Downey, D.B.; Ainsworth, J.W.; Qian, Z. Rethinking the attitude-achievement paradox among blacks. Sociol. Educ. 2009, 82, 1-19. [CrossRef]

22. Harris, A.L. Optimism in the face of despair: Black-white differences in beliefs about school as a means for upward social mobility. Soc. Sci. Q. 2008, 89, 608-630. [CrossRef]

23. Pronin, E.; Ross, L. Temporal differences in trait self-ascription: When the self is seen as another. J. Pers. Soc. Psychol. 2006, 90, 197-209. [CrossRef] [PubMed]

24. Ross, L.; Lepper, M.; Ward, A. History of social psychology: Insights, challenges, and contributions to theory and application. In Handbook of Social Psychology; John Wiley \& Sons, Inc.: Hoboken, NJ, USA, 2010; ISBN 978-0-470-56111-9.

25. Lerner, M.J. The Belief in a Just World. A Fundamental Delusion; Plenum Press: New York, NY, USA, 1980.

26. Delhey, J.; Dragolov, G. Why inequality makes europeans less happy: The role of distrust, status anxiety, and perceived conflict. Eur. Sociol. Rev. 2014, 30, 151-165. [CrossRef]

27. McCall, L. The Undeserving Rich. American Beliefs about Inequality, Opportunity, and Redistribution; Cambridge University Press: New York, NY, USA, 2013.

28. Hauser, O.P.; Norton, M.I. (Mis) perceptions of inequality. Curr. Opin. Psychol. 2017, 18, 21-25. [CrossRef] [PubMed]

29. Kenworthy, L.; McCall, L. Inequality, public opinion and redistribution. Socio-Econ. Rev. 2008, 6, 35-68. [CrossRef]

30. Kay, A.C.; Gaucher, D.; Peach, J.M.; Laurin, K.; Friesen, J.; Zanna, M.P.; Spencer, S.J. Inequality, discrimination, and the power of the status quo: Direct evidence for a motivation to see the way things are as the way they should be. J. Pers. Soc. Psychol. 2009, 97, 421-434. [CrossRef] [PubMed]

31. McCoy, S.K.; Major, B. Priming meritocracy and the psychological justification of inequality. J. Exp. Soc. Psychol. 2007, 43, 341-351. [CrossRef]

32. Newman, K.S. Falling from Grace: Downward Mobility in the Age of Affluence; University of California Press: Berkeley, CA, USA, 1999.

33. Rondini, A.C. Healing the hidden injuries of class? Redemption narratives, aspirational proxies, and parents of low-income, first-generation college students. Sociol. Forum 2016, 31, 96-116. [CrossRef]

34. Croll, P.R. Explanations for racial disadvantage and racial advantage: Beliefs about both sides of inequality in America. Ethn. Racial Stud. 2013, 36, 47-74. [CrossRef]

35. Huber, J.; Form, W.H. Income and Ideology: An Analysis of the American Political Formula; Free Press: New York, NY, USA, 1973; ISBN 9780029153307.

36. Jost, J.T.; Banaji, M.R. The role of stereotyping in system-justification and the production of false consciousness. Br. J. Soc. Psychol. 1994, 33, 1-27. [CrossRef]

37. Sharone, O. Why do unemployed Americans blame themselves while Israelis blame the system? Soc. Forces 2013, 91, 1429-1450. [CrossRef]

38. Choi, I.; Nisbett, R.E.; Norenzayan, A. Causal attribution across cultures: Variation and universality. Psychol. Bull. 1999, 125, 47-63. [CrossRef]

39. Calhoun, L.G.; Cann, A. Differences in assumptions about a just world: Ethnicity and point of view. J. Soc. Psychol. 1994, 134, 765-770. [CrossRef] 
40. Hunt, M.O. Status, religion, and the "belief in a just world": Comparing African Americans, Latinos, and Whites. Soc. Sci. Q. 2000, 81, 325-343.

41. Jost, J.T.; Banaji, M.R.; Nosek, B.A. A decade of system justification theory: Accumulated evidence of conscious and unconscious bolstering of the status quo. Polit. Psychol. 2004, 25, 881-919. [CrossRef]

42. Crittenden, K.S. Sociological aspects of attribution. Annu. Rev. Sociol. 1983, 9, 425-446. [CrossRef]

43. Arsenio, W.F.; Willems, C. Adolescents' conceptions of national wealth distribution: Connections with perceived societal fairness and academic plans. Dev. Psychol. 2017, 53, 463-474. [CrossRef] [PubMed]

44. Grayman, J.K.; Godfrey, E.B. Social justice attitudes and their demographic correlates among a nationally representative sample of U.S. adolescents. Soc. Justice Res. 2013, 26, 422-444. [CrossRef]

45. Hunt, M.O. The Individual, society, or both? A comparison of Black, Latino, and White beliefs about the causes of poverty. Soc. Forces 1996, 75, 293-322. [CrossRef]

46. Kluegel, J.R. Trends in Whites' explanations of the Black-White gap in socioeconomic status, 1977-1989. Am. Sociol. Rev. 1990, 55, 512-525. [CrossRef]

47. Kunovich, S.; Slomczynski, K.M. Systems of distribution and a sense of equity: A multilevel analysis of meritocratic attitudes in post-industrial societies. Eur. Sociol. Rev. 2007, 23, 649-663. [CrossRef]

48. Lavrijsen, J.; Nicaise, I. Ascription, achievement, and perceived equity of educational regimes: An empirical investigation. Soc. Sci. 2016, 5, 64. [CrossRef]

49. Reynolds, J.; Xian, H. Perceptions of meritocracy in the land of opportunity. Res. Soc. Stratif. Mobil. 2014, 36, 121-137. [CrossRef]

50. Barnes, S.L. Achievement or Ascription Ideology? An Analysis of Attitudes about Future Success for Residents in Poor Urban Neighborhoods. Sociol. Focus 2002, 35, 207-225. [CrossRef]

51. Wilson, G. Toward a Revised Framework for Examining Beliefs about the Causes of Poverty. Sociol. Q. 1996, 37, 413-428. [CrossRef]

52. Bauman, C.W.; Skitka, L.J. Ethnic Group Differences in Lay Philosophies of Behavior in the United States. J. Cross-Cult. Psychol. 2006, 37, 438-445. [CrossRef]

53. Newman, B.J.; Johnston, C.D.; Lown, P.L. False Consciousness or Class Awareness? Local Income Inequality, Personal Economic Position, and Belief in American Meritocracy. Am. J. Polit. Sci. 2015, 59, 326-340. [CrossRef]

54. Bullock, H.E. Attributions for Poverty: A Comparison of Middle-Class and Welfare Recipient Attitudes1. J. Appl. Soc. Psychol. 1999, 29, 2059-2082. [CrossRef]

55. Hunt, M.O. African American, Hispanic, and White Beliefs about Black/White Inequality, 1977-2004. Am. Sociol. Rev. 2007, 72, 390-415. [CrossRef]

56. Merolla, D.M.; Hunt, M.O.; Serpe, R.T. Concentrated disadvantage and beliefs about the causes of poverty: A multi-level analysis. Sociol. Perspect. 2011, 205-228. [CrossRef]

57. Taylor, M.C.; Merino, S.M. Race, Religion, and Beliefs about Racial Inequality. Ann. Am. Acad. Pol. Soc. Sci. 2011, 634, 60-77. [CrossRef]

58. Hochschild, J.L. Facing Up to the American Dream: Race, Class, and the Soul of the Nation; Princeton University Press: Princeton, NJ, USA, 1996; ISBN 1-4008-2173-8.

59. Piketty, T. Capital in the Twenty-First Century; Harvard University Press: Cambridge, MA, USA, 2014.

60. Bourdieu, P. Distinction: A Social Critique of the Judgement of Taste; Harvard University Press: Cambridge, MA, USA, 1984; ISBN 978-0-674-21277-0.

61. Evans, G. Political Ideology and Popular Beliefs about Class and Opportunity: Evidence from a Survey Experiment. Br. J. Sociol. 1997, 48, 450-470. [CrossRef] [PubMed]

62. Gerber, A.; Green, D. Misperceptions About Perceptual Bias. Annu. Rev. Polit. Sci. 1999, 2, $189-210$. [CrossRef]

63. Hagan, J.; Shedd, C.; Payne, M.R. Race, Ethnicity, and Youth Perceptions of Criminal Injustice. Am. Sociol. Rev. 2005, 70, 381-407. [CrossRef]

64. Gurin, P.; Dey, E.; Hurtado, S.; Gurin, G. Diversity and Higher Education: Theory and Impact on Educational Outcomes. Harv. Educ. Rev. 2002, 72, 330-367. [CrossRef]

65. Margalit, Y. Explaining Social Policy Preferences: Evidence from the Great Recession. Am. Polit. Sci. Rev. 2013, 107, 80-103. [CrossRef]

66. Piaget, J. The Development of Thought: Equilibration of Cognitive Structures; Viking Press: New York, NY, USA, 1975. 
67. Edmiston, D. The poor "sociological imagination" of the rich: Explaining attitudinal divergence towards welfare, inequality, and redistribution. Soc. Policy Adm. 2018, 53, 1-15. [CrossRef]

68. Newman, B.J.; Velez, Y.; Hartman, T.K.; Bankert, A. Are Citizens "Receiving the Treatment"? Assessing a Key Link in Contextual Theories of Public Opinion and Political Behavior. Polit. Psychol. 2015, 36, 123-131. [CrossRef]

69. Xu, P.; Garand, J.C. Economic Context and Americans' Perceptions of Income Inequality. Soc. Sci. Q. 2010, 91, 1220-1241. [CrossRef]

70. Sampson, R.J.; Bartusch, D.J. Legal cynicism and (subcultural?) tolerance of deviance: The neighborhood context of racial differences. Law Soc. Rev. 1998, 32, 777-804. [CrossRef]

71. Duncan, G.J.; Murnane, R.J. Whither Opportunity? Rising Inequality, Schools, and Children's Life Chances; Russell Sage Foundation: New York, NY, USA, 2011; ISBN 978-1-61044-751-5.

72. Galster, G.; Sharkey, P. Spatial foundations of inequality: A conceptual model and empirical overview. RSF 2017, 3, 1-33. [CrossRef]

73. Sharkey, P. The intergenerational transmission of context. Am. J. Sociol. 2008, 113, 931-969. [CrossRef]

74. Shedd, C. Unequal City. Race, Schools, and Perceptions of Injustice; Russell Sage Foundation: New York, NY, USA, 2015.

75. Alwin, D.F.; Krosnick, J.A. Aging, cohorts, and the stability of sociopolitical orientations over the life span. Am. J. Sociol. 1991, 97, 169-195. [CrossRef]

76. Sears, D.O.; Funk, C.L. Evidence of the long-term persistence of adults' political predispositions. J. Polit. 1999, 61, 1-28. [CrossRef]

77. Sears, D.O.; Levy, S. Childhood and adult political development. In Handbook of Political Psychology; Sears, D.O., Huddy, L., Jervis, R., Eds.; Oxford University Press: New York, NY, USA, 2003; pp. 60-109.

78. Cruces, G.; Perez-Truglia, R.; Tetaz, M. Biased perceptions of income distribution and preferences for redistribution: Evidence from a survey experiment. J. Public Econ. 2013, 98, 100-112. [CrossRef]

79. Vaisey, S. Motivation and justification: A dual-process model of culture in action. Am. J. Sociol. 2009, 114, 1675-1715. [CrossRef] [PubMed]

80. Zaller, J.R. The Nature and Origins of Mass Opinion; Cambridge University Press: Cambridge, UK, 1992; ISBN 978-0-521-40786-1.

81. Allport, G.W. The Nature of Prejudice; Basic Books: New York, NY, USA, 1954; ISBN 0-201-00179-9.

82. Cech, E.A.; Blair-Loy, M. Perceiving glass ceilings? Meritocratic versus structural explanations of gender inequality among women in science and technology. Soc. Probl. 2010, 57, 371-397. [CrossRef]

83. Cech, E.A.; Blair-Loy, M.; Rogers, L.E. Recognizing chilliness: How schemas of inequality shape views of culture and climate in work environments. Am. J. Cult. Sociol. 2016, 1-36. [CrossRef]

84. Seron, C.; Silbey, S.; Cech, E.; Rubineau, B. “I am not a feminist, but ... ": Hegemony of a meritocratic ideology and the limits of critique among women in engineering. Work Occup. 2018, 45, 131-167. [CrossRef]

85. Kanter, R.M. Men and Women of the Corporation; Basic Books: New York, NY, USA, 1977; ISBN 978-0-465-04454-2.

86. Ridgeway, C.L. Inequality, status, and the construction of status beliefs. In Handbook of Sociological Theory; Turner, J.H., Ed.; Kluwer Academic: New York, NY, USA, 2001; pp. 323-340.

87. Correll, S.J. Constraints into preferences: Gender, status, and emerging career aspirations. Am. Sociol. Rev. 2004, 69, 93-113. [CrossRef]

88. Minkoff, S.L.; Lyons, J. Living with inequality: Neighborhood income diversity and perceptions of the income gap. Am. Polit. Res. 2018, in press. [CrossRef]

89. Wu, A.M.; Chou, K.-L. Public attitudes towards income redistribution: Evidence from Hong Kong. Soc. Policy Adm. 2017, 51, 738-754. [CrossRef]

90. Mijs, J.J.B. Stratified failure educational stratification and students' attributions of their mathematics performance in 24 countries. Sociol. Educ. 2016, 89, 137-153. [CrossRef]

91. Sidanius, J.; Levin, S.; Laar, C.V.; Sears, D.O. The Diversity Challenge: Social Identity and Intergroup Relations on the College Campus; Russell Sage Foundation: New York, NY, USA, 2010; ISBN 978-0-87154-794-1.

92. Mendelberg, T.; McCabe, K.T.; Thal, A. College socialization and the economic views of affluent Americans. Am. J. Polit. Sci. 2017, 61, 606-623. [CrossRef]

93. Mijs, J.J.B. Institutions as Inferential Spaces: How People Learn About Inequality. Ph.D. Thesis, Harvard University, Cambridge, MA, USA, 2017. 
94. Khan, S.R. Privilege: The Making of an Adolescent Elite at St. Paul's School; Princeton University Press: Princeton, NJ, USA, 2010; ISBN 1-4008-3622-0.

95. Gaztambide-Fernández, R. The Best of the Best: Becoming Elite at an American Boarding School; Harvard University Press: Cambridge, MA, USA, 2009; ISBN 978-0-674-03568-3.

96. Small, M.L.; Harding, D.J.; Lamont, M. Reconsidering culture and poverty. Ann. Am. Acad. Pol. Soc. Sci. 2010, 629, 6-27. [CrossRef]

97. Giuliano, P.; Spilimbergo, A. Growing up in a recession. Rev. Econ. Stud. 2014, 81, 787-817. [CrossRef]

(C) 2018 by the author. Licensee MDPI, Basel, Switzerland. This article is an open access article distributed under the terms and conditions of the Creative Commons Attribution (CC BY) license (http://creativecommons.org/licenses/by/4.0/). 